\title{
JNPH
}

Volume 6 No. 1 (April 2018)

(C) The Author(s) 2018

\section{LAMANYA PAPARAN KARBON MONOKSIDA TERHADAP PROFIL ENZIM ALANIN AMINOTRANFERASE}

\author{
DURATION EXPOSURE OF CARBON MONOXIDE AGAINST \\ ENERGY PROFILE ALANIN AMINOTRANFERASE
}

\author{
RADEN SUNITA \\ POLTEKKES KEMENKES BENGKULU JURUSAN ANALIS KESEHATAN \\ Email: zawarasunita@yahoo.co.id
}

\begin{abstract}
ABSTRAK
Latar Belakang: Karbon Monoksida (CO) merupakan senyawa berupa gas yang tidak berwarna, tidak berbau dan tidak berasa. Karbon monoksida berasal dari pembakaran yang tidak sempurna seperti pembakaran kayu bakar. Kayu bakar merupakan bahan bakar utama yang digunakan dalam pembuatan tahu di pabrik tahu. Asap pembakaran kayu pada pabrik tahu mengandung gas CO yang mampu mencemari udara, sehingga dapat menimbulkan gangguan berupa mata kemerahan, cepat haus, kepala pusing dan sesak nafas. Gangguan ini dapat terjadi pada pekerja pabrik tahu yang terpapar CO. Karbon Monoksida masuk ke dalam tubuh pada tingkat lama paparan tertentu menyebabkan perubahan beberapa molekul tubuh dan akhirnya mengganggu fungsi tubuh. Salah satu organ ikut mengalami perubahan akibat paparan $\mathrm{CO}$ berlebihan adalah hati ditandai meningkatnya kadar enzim Alanin Aminotransferase (ALT).Tujuan Penelitian: Untuk menganalisis lamanya paparan karbon monoksida terhadap profil enzim Alanin Aminotranferase. Metode: Menggunakan desain Cross Sectional dengan sampel 34 responden. serum pekerja pabrik tahu diperiksa kadar ALT menggunakan spektofotometer Mindray BA88A. Data dianalisis dengan menggunakan uji Korelasi Spearman. Hasil : Lama paparan CO pada pekerja pabrik tahu diperoleh mean (4,06 tahun), median (4,00 tahun), nilai minimun (1 tahun) dan maksimum (7 tahun). Kadar enzim ALT pada pekerja pabrik tahu diperoleh mean $(33,82 \mathrm{U} / \mathrm{L})$, median $(33.00 \mathrm{U} / \mathrm{L})$, nilai minimum $(8 \mathrm{U} / \mathrm{L})$ dan nilai maximum $(56 \mathrm{U} / \mathrm{L})$. Terdapat hubungan lama paparan CO terhadap kadar ALT $(r=0,783 ; p<0,001 ; n=34)$. Kesimpulan : Semakin lama pekerja pabrik tahu terpapar CO, semakin tinggi kadar ALT. Pekerja pabrik tahu sebaiknya mengurangi paparan karbon monosida dengan melakukan pergantian bidang pekerjaan dan memperhatikan penggunan alat pelindung diri pada saat bekerja.
\end{abstract}

Kata Kunci : Karbon Monoksida, Pekerja Pabrik Tahu, Alanin Aminotransferase.

\begin{abstract}
Background: Carbon Monoxide (CO) is a gas compound that is colorless, odorless and tasteless. Carbon monoxide comes from incomplete combustion such as burning firewood. Firewood is the main fuel used in tofu manufacturing in tofu factories. Wood-burning smoke in the tofu plant contains CO gas capable of polluting the air, so it can cause disturbance in the form of reddish eyes, quick thirst, headache and shortness of breath. This disorder can occur in exposed to factory workers who are exposed to CO. Carbon Monoxide enters the body at a certain level of exposure causing changes in some of the body's molecules and ultimately
\end{abstract}


disrupts the functioning of the body. One of the organs involved changes due to excessive $\mathrm{CO}$ exposure is the liver characterized by increased levels of enzyme Alanin Aminotransferase (ALT). Research Objectives: To analyze the duration of carbon monoxide exposure to the enzyme profile Alanin Aminotranferase. Method: Using Cross Sectional design with 34 respondents. serum of factory workers know checked ALT levels using Mindray BA-88A speculator. Data were analyzed using Spearman Correlation test. Result: Exposure time of CO to factory worker to know obtained mean (4.06 years), median (4.00 years), minimum value (1 year) and maximum (7 years). Levels of ALT enzyme in factory workers know obtained mean $(33,82 \mathrm{U} / \mathrm{L})$, median $(33.00 \mathrm{U} / \mathrm{L})$, minimum value $(8 \mathrm{U} / \mathrm{L})$ and maximum value $(56 \mathrm{U} / \mathrm{L})$. There is a long relationship of CO exposure to ALT levels $(r=0.783 ; p<0.001 ; n=34)$. Conclusion: The longer the factory workers know exposed to $\mathrm{CO}$, the higher the ALT level. Factory workers know to reduce carbon monoside exposure by changing jobs and pay attention to the use of personal protective equipment when working.

Keywords: Carbon Monoxide, Factory Worker Tofu, Alanine Aminotransferase.

\section{PENDAHULUAN}

Kadar Alanin Aminotranferase (ALT) sebagai salah satu biomarker kerusakan hati. Enzim ALT berupa enzim transferase yang akan keluar ketika hati mengalami kerusakan. Tingkat kerusakan hati biasanya dapat dilihat dari adanya peningkatan kadar ALT lebih dari angka normal ${ }^{1}$. Kasus kerusakan hati menurut WHO menduduki peringkat ke delapan belas di dunia dengan prevalensi $1,3 \%$, dan di Indonesia $(1,7 \%)^{2}$.

Kerusakan hati dapat terjadi akibat paparan sel hati terhadap zat toksis pada dosis dan waktu tertentu dalam proses detoksifikasi. Proses detoksifikasi dilakukan dengan cara mengubah semua bahan asing atau toksin menjadi bahan yang tidak membahayakan tubuh. Kemampuan hati dalam mendetoksifikasi ini terbatas sehingga dapat menimbulkan kerusakan pada organ hati. Organ hati memiliki kapasitas yang tinggi dalam mengikat bahan kimia. Salah satu bahan kimia bersifat toksik adalah gas karbon monoksida $(\mathrm{CO})^{3}$.

Karbon monoksida bersifat sangat toksik jika terhirup oleh manusia. Karbon monoksida dihasilkan dari pembakaran yang tidak sempurna. Pada suhu udara normal, karbon monoksida berbentuk gas yang tidak berwarna, tidak berbau dan tidak berasa. Karbon monoksida yang terhirup oleh manusia akan masuk ke dalam saluran pernapasan lalu menuju paru-paru dan kemudian menempel pada haemoglobin darah membentuk carboxy haemoglobin $(\mathrm{COHb})$. Karbon monoksida memiliki kemampuan berikatan dengan haemoglobin yang jauh lebih kuat 200 kali dari oksigen yang mengakibatkan $\mathrm{CO}$ menggantikan posisi oksigen yang berikatan dengan haemoglobin 4.

Persentasi $\mathrm{COHb}$ dalam tubuh akibat paparan $\mathrm{CO}$ menimbulkan gejala-gejala antara lain pusing kepala (10\%), mual dan sesak nafas (20\%), gangguan penglihatan dan konsentrasi menurun $(30 \%)$, tidak sadar atau koma (40-50\%) dan apabila berlanjut akan dapat menyebabkan kematian ${ }^{5}$. Selain itu dampak kesehatan lainnya seperti miokarditis, edema paru, bronkopneumonia, pankreatitis, kerusakan ginjal, albuminuria, glikosuria, oliguria, hepatomegali dan kerusakan hati ${ }^{6}$.

Karbon monoksida bersumber dari hasil pembakaran yang tidak sempurna seperti asap kendaraan, asap rokok, asap tungku pabrik, asap tungku dapur rumah tangga, dan asap pembakaran kayu bakar ${ }^{6}$. Pembakaran dengan kayu bakar masih sering digunakan di sekitar 50 persen populasi di dunia, dan 90 persen populasi di negara berkembang ${ }^{7}$.

Pembakaran kayu menghasilkan karbon monoksida dengan konsentrasi 5000 ppm dalam sekali pembakaran. Sedangkan baku mutu karbon monoksida di udara menurut OSHA (Occupational Safety and Health Administration) adalah 35 ppm untuk waktu 8 
jam/hari kerja. Kadar yang dianggap langsung berbahaya terhadap kehidupan atau kesehatan adalah 1500 ppm (0,15\%). Paparan dari 1000 ppm $(0,1 \%)$ selama beberapa menit dapat menyebabkan 50\% kejenuhan dan karboksi hemoglobin dan dapat berakibat fatal ${ }^{8}$.

Pembakaran menggunakan kayu bakar tidak hanya digunakan pada tungku dapur rumah tangga, namun juga masih banyak digunakan sebagai bahan bakar industri tradisional, seperti pabrik tahu. Pembuatan tahu dilakukan di dalam tungku dengan pemanasan langsung menggunakan panas hasil pembakaran bahan bakar berupa kayu, sebuk gergaji, atau bahan bakar padat lainnya ${ }^{9}$.

Berdasarkan survei pendahuluan yang dilaksanakan di Kelurahan Sidorejo Curup merupakan salah satu kelurahan dengan jumlah pabrik tahu terbanyak yaitu lima pabrik tahu dengan total pekerja 52 orang. Pengolahan tahu di pabrik ini masih dilakukan dengan cara tradisional seperti penggunaan bahan bakar kayu dan dilakukan selama $>8$ jam kerja per hari. Data yang di peroleh dan hasil wawancara pada pekerja pabrik tahu di Kelurahan Sidorejo Curup, ada pekerja pabrik yang mengalami gangguan kesehatan pada saat pembuatan tahu terutama pada pengadukan adonan tahu dan penggorengan tahu yang dilakukan langsung di depan tungku pembakaran dan membutuhkan waktu yang lama. Gangguan tersebut berupa mata kemerahan, cepat haus, kepala pusing dan sesak nafas. Gejala sama dengan kasus keracunan $\mathrm{CO}$ yang mengakibatkan kerusakan hati. Kasus kerusakan hati tertinggi di Provinsi Bengkulu tercatat di Curup dengan jumlah 18 kasus dari total 26 kasus pada bulan Agustus 2016 (Dinkes Rejang Lebong 2016). Melihat permasalahan diatas, maka penting dilakukan penelitian mengenai lama paparan karbon monoksida pada pekerja pabrik tahu.

\section{METODE PENELITIAN}

Penelitian ini menggunakan survei analitik dengan pendekatan laboratorium.
Penelitian ini dilaksanakan pada bulan November 2016 - Februari 2017. Sampel penelitian ini diambil dengan metode Simple Random Sampling yang terdiri dari 34 orang responden yang dipilih secara acak setelah memenuhi kriteria inklusi sampel.

\section{HASIL PENELITIAN}

Hasil analisis penelian Alanin Aminotransferase (ALT) pada pekerja pabrik tahu di Kelurahan Sidorejo Curup dilakukan pada 34 responden dengan hasil distribusi frekuensi kadar ALT yang disajikan pada tabel.1 di bawah ini.

\section{Tabel. 1 Distribusi Frekuensi Lama Paparan CO dan kadar ALT}

\begin{tabular}{|c|c|c|c|c|c|}
\hline Pariabel & $\mathrm{N}$ & Meati & Median & $\begin{array}{c}\text { Nifai } \\
\text { Minimum }\end{array}$ & $\begin{array}{c}\text { Milai } \\
\text { Matcsimum }\end{array}$ \\
\hline $\begin{array}{c}\text { Latna Paparan } \\
\text { Karbon Monocsida }\end{array}$ & 34 & 4,06 & 4,00 & 1 & 7 \\
\hline Kadar ALT & 34 & 3382 & 3300 & $\delta$ & 56 \\
\hline
\end{tabular}

Berdasarkan Tabel.1 diketahui rata-rata lama paparan Karbon Monoksida (CO) adalah 4,06 Tahun, dengan nilai tengah 4,00 tahun, nilai minimum 1 tahun dan nilai maksimum 7 tahun. Rata-rata kadar ALT adalah 33,82 U/L, menunjukkan kadar ALT pekerja pabrik tahu masih normal (0-40 U/L). Dari data pada tabel.1 distribusi yang menggunakan uji Shapiro Wilk didapatkan data yang digunakan terdistribusi tidak normal $(p<0,05)$. Kemudian analisa data dilanjutkan dengan melakukan uji non parametrik yaitu Korelasi Spearman.

\section{Tabel.2 Hubungan Lama Paparan CO terhadap Kadar ALT}

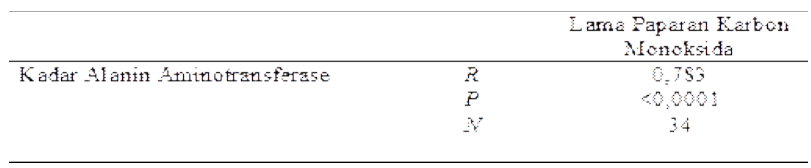

Dari tabel.2 diatas, tabel terdiri dari koefisien korelasi (r), nilai (p), dan jumlah objek (n). Nilai $(p<0,001)$ dibawah nilai $p>0,05$ yang menunjukkan bahwa terdapat korelasi yang bermakna antara dua variabel 
yaitu lama paparan karbon monoksida dan kadar Alanin Aminotransferase (ALT). Nilai Korelasi Spearman adalah 0,783 yang menunjukkan bahwa arah korelasi positif dengan kekuatan korelasi yang Kuat. Nilai korelasi positif didapatkan dari arah korelasi yang searah, semakin besar nilai lama paparan karbon monoksida (CO) semakin tinggi pula kadar enzim Alanin Aminotransferase(ALT).

\section{PEMBAHASAN}

Penelitian yang sudah dilakukan, dihasilkan sampel yang memiliki kadar Alanin Amino Transferase (ALT) abnormal berjumlah 16 orang (47\%), sedangkan responden yang memiliki kadar Alanin Amino Transferase (ALT) normal berjumlah 18 orang (53\%). Kadar ALT abnormal terjadi pada pekerja dengan lama paparan $\geq 4$ tahun yaitu lebih dari nilai rata-rata lama paparan karbon monoksida terhadap pekerja pabrik tahu.

Hasil penelitian ini menunjukkan bahwa semakin besar nilai lama paparan $\mathrm{CO}$ semakin tinggi pula kadar enzim ALT. Hasil sesuai dengan penelitian oleh Apriana pada tahun 2015 yang menjelaskan bahwa terdapat pengaruh lama paparan Karbon Monoksida (CO) terhadap kadar Alanin Aminotransferase $(A L T)$ yang menunjukan terjadinya kerusakan fungsi hati.

Kerusakan hati dapat terjadi akibat dari proses detoksifikasi yang merupakan salah satu fungsi hati. Proses detoksifikasi dilakukan dengan cara mengubah semua bahan asing atau toksin menjadi bahan yang tidak membahayakan tubuh. Kemampuan hati dalam mendetoksifikasi ini terbatas sehingga dapat menimbulkan kerusakan pada organ hati. Bahan asing atau toksin yang dapat memacu terjadinya proses detoksifikasi salah satunya adalah karbon monoksida. ${ }^{10}$

Proses detoksifikasi dari karbon monoksida di hati terjadi di dalam peroxisomal melalui proses reaksi peroxidative dengan bantuan enzim peroximal catalas dengan menggunakan $\mathrm{H}_{2} \mathrm{O}_{2}$. Reaksi antara karbon dengan $\mathrm{H}_{2} \mathrm{O}_{2}$ dan radikal reaktif spesies yang lain akan menghasilkan radikal hidroksietil yang merupakan oksidan kuat. Reaksi hidroksietil tersebut dapat mengoksidasi lipid dan protein oleh bantuan enzim peroximal catalase dengan menggunakan $\mathrm{H}_{2} \mathrm{O}_{2}$. Enzim aldehida dehidrogenase di ubah menjadi asam asetat. Asam asetat dioksidasi menjadi $\mathrm{CO}^{2}$ dan $\mathrm{H}_{2} \mathrm{O}$. Alanin aminotranferase akan mempercepat metabolisme karbon monoksida. Perlindungan terhadap hepatotoksisitas oleh suatu zat dinilai berdasarkan kemampuannya untuk mempengaruhi berbagai parameter antara lain menekan peningkatan aktivitas enzim-enzim aminotransminase. Enzim enzim ini keluar dari sel-sel hati sehingga kadarnya meningkat dalam darah ${ }^{3}$.

Pada mekanisme detoksifikasi tersebut jika seseorang terpapar karbon monoksida secara terus-menerus maka akan mengganggu kesehatan, terutama kesehatan hati. Hal ini dikarenakan organ hati memiliki kapasitas yang tinggi dalam mengikat bahan kimia dan toksik sehingga bahan kimia banyak terkonsentrasi pada organ hepar dibandingkan dengan organ lainnya. Pekerja pabrik tahu merupakan salah satu contoh dari pekerja yang beresiko terpapar $\mathrm{CO}$ secara terus menerus ${ }^{11}$.

Berdasarkan observasi saya pada saat melakukan pengambilan sampel, pekerja pabrik tahu tidak menggunakan alat pelindung diri saat bekerja, namun pemaparan CO pada setiap pekerja berbeda-beda, ada yang terpapar secara langsung dan tidak langsung. Pemaparan $\mathrm{CO}$ tergantung pada jenis pengerjaan masing-masing yang ikut mempengaruhi peningkatan kadar ALT. Pekerja pabrik tahu merasakan gangguan akibat dari paparan $\mathrm{CO}$ berupa mata kemerahan, sesak napas dan kepala pusing. Dengan tidak menggunakan alat perlindungan diri maka ketika mereka telah terpapar tidak menutup kemungkinan akan menyebabkan terjadinya kerusakan pada organ hati yang ditandai dengan meningkatnya nilai enzim ALT pada tubuh mereka. 
Hubungan lama paparan CO terhadap kadar enzim ALT pada pekerja pabrik tahu di Kelurahan Sidorejo Curup di karenakan pemaparan $\mathrm{CO}$ dalam jangka waktu cukup lama dapat mengakibatkan kerusakan hati. Kerusakan hati diawali dengan perubuhan permeabilitas membran yang diikuti dengan kematian sel. Enzim ALT berperan dalam mengkatalis pemindahan gugus amino dari alanin ke asam alfa ketoglutarat membentuk asam glutamat dan asam piruvat. Enzim ALT merupakan indikator terbaik dalam melihat kerusakan hati. Pada gangguan sel hati maka enzim sitoplasma akan merembes ke dalam serum terutama enzim ALT. Oleh karena itu, aktivitas enzim ALT bersifat khas dan spesifik terhadap kerusakan hati sehingga sangat cocok sebagai tes untuk menentukan adanya gangguan fungsi hati ${ }^{6}$.

\section{KESIMPULAN}

Hasil penelitian ini menunjukkan bahwa Ada hubungan lama paparan karbon monoksida (CO) terhadap kadar enzim Alanin Amino Transferase (ALT)

\section{SARAN}

Bagi pemilik pabrik tahu untuk membuat jadwal pergantiaan bidang pekerjaan sehingga dapat menggurangi lama paparan Karbon Monoksida.

Bagi pekerja pabrik tahu untuk mematuhi jadwal pergantian bidang pekerjaan dan memperhatikan penggunaan alat perlindungan diri agar mengurangi paparan karbon monoksida secara langsung.

Bagi masyarakat untuk lebih memperhatikan dampak buruk dari asap pembakaran pabrik dan pembakaran tungku dapur rumah tanggadengan mencari alternatif bahan bakar yang sedikit menghasilkan $\mathrm{CO}$, seperti pengunaan gas elpiji untuk masyarakat sekitar dan penggunaan bahan bakar briket untuk para pekerja pabrik tahu

Bagi peneliti lain untuk melakukan penelitian lebih lanjut dengan jumlah sampel yang lebih banyak dan variabel cakupan yang lebih luas.

\section{DAFTAR PUSTAKA}

Agusta D. Uji Adsorpsi Gas CO pada Asap Kebakaran dengan Menggunakan Karbon Aktif dari Arang Tempurung Kelapa yang Terimpregnasi $\mathrm{TiO} 2$. Universtas Indonesa. 2012:81.

Apriana AD. Pengaruh Lama Paparan CO terhadap Kadar ALT ( Alanin Aminotransferase ) Effects of Long Exposure $\mathrm{CO}$ to ALT ( Alanine Aminotransferase ) Level. FKUL. 2015;4(November):139-142.

Fatoni R, Septiani T, Mikasasari RP. Kajian Tekno-Ekonomis Pabrik Tahu Bubur kedelai ( Soybean Slurry ) Susu kedelai ( Soy milk ) Protein Abu tanpa garam Serat kasar Logam berbahaya ( As , Pb , $\mathrm{Mg}$, Zn ) Zat warna Bau dan rasa Kondisi Zat pengawet Minimal $9 \%$ Maksimal $1 \%$ Negatif Pewarna khu. Universty Res Coloquium. 2016:22-28.

Fernando B, Supriyanto A, Suciyati SW. Realisasi Alat Ukur Konsentrasi Karbon Monoksida ( CO ) pada Gas Buang Kendaraan Bermotor Berbasis Sensor Gas TGS 2201 dan Mikrokontroler ATMega8535. FMIPA Univ Lampung. 2013;1(1):43-47.

Hernawati. Gambaran Efek Toksik Etanol Pada Sel Hati. FPMIPA Univ Pendidik Indones. 2008;(229):1-20.

Malau AS. Karakteristik Penderita Sirosis Hati yang Dirawat Inap Di Rumah Sakit Martha FriskaMedan Tahun 2006-2010. Univ Sumatera Utara. 2011.

Maryanto D, Mulasari SA, Suryani D. Penurunan Kadar Emisi Gas Buang Karbon Monoksida ( $\mathrm{CO}$ ) Dengan Penambahan Arang Aktif. Kesehat Masy. 2009;3(3):198-204.

Primelya A, Wisnu I, Istirokhatun T. Pengaruh

Kelembaban Kayu Terhadap Konsentrasi PM2.5 dan Black Carbon : Analisis Dari Skala Laboratorium dan Lapangan. PT Ganesha Environ Energy Serv Bandung. 2008:1-15. 
Suaniti NM, Djelantik AAGS, Suastika K, Astawa NM. Aldehid Dehidrogenase Dalam Tikus Wistar Sebagai Biomarker Awal Konsumsi Alkohol Secara Akut Aldehyde Dehydrogenase in Sera Rat Wistar as Early Biomarker in Acute Alcohol Consumption Pemeriksaan Jaringan hati yang normal di adanya sel parenkim dan sel lai. $J$ Biol. 2011;15(1):6-8.

Tampubolon SR, Ardana IBK, Sudira I wayan. Aktivitas Alanin Aminotransferase dan Aspartat Aminotransferase Pada Mencit yang Diberikan Jamu Temulawak. Indones Med Veterinus. 2014;3(3):200-205.

Tatukude RL, Loho L, Lintong MP. Gambaran Histopatologi Hati Tikus Wistar yang Diberikan Boraks. $J e$ Biomedik. 2014;2(3):1-7. 